\title{
Nilai Dakwah Dalam Tradisi Maulid Nabi Muhammad Saw Pada Jama'ah Masjid Al - Huda Desa Karang Joho Kecamatan Badegan
}

\author{
Fenti Fatmawati \\ Institut Agama Islam Sunan Giri Ponorogo \\ fentifatma@gmail.com
}

\begin{abstract}
Abstrak
Tujuan dari penelitian nilai dakwah dalam tradisi maulid nabi jama'ah masjid al huda untuk mengetahui bagaiman pelaksanaan tradisi maulid nabi dan nilai dakwah apa saja yang terkandung di dalam tradisi tersebut, ta'mir masjid yang bertanggung jawab atas pelaksanaan mauid nabi tersebut harus mengetahui bagaiman alatar belakang jama'ah masjid al huda, agar pelaksanaan maulid nabi tudak hanya sekedar agenda tahunan bagi mereka. Melalui hal itu pelaksanaan maulid nabi lebih mengesankan dan mempunyai kesan baik pada jam'ah masjid al huda, hal ini tentunya adanyaa nilai yang terkandung didalamnya Dalam penelitian ini penulis menggunakan pendekatan sosiologis dengan melakukan observasi partisipisan dan wawancara sebagai metode utama pengumpulan datanya. Sedangkan metode yang digunakan kualitatif diskriptif yang memiliki karakteristik sumber data langsung, deskriptif .bersifat triangulation yaitu teknik pemeriksaan data dengan memanfaatkan sesuatu yang lain sebagai pembanding diluar data yang ditemukan, pengambilan subjek di lingkungan jama'ah masjid al huda.Kesimpulan dari penelitian ini adalah Latar belakang pendidikan dan minimnya wadah informasi pada waktu itu yang membuat para jama'ah kurang memahami atau memaknai dengan baik maulid nabi sebenarya. melalui hal hal yang kecil dalam pelaksanaan maulid nabi di lingkungan masjid al huda membuat jamaah lebih mengambil nilai di dalamnya, kesederhanaan ambengan (makanan) misalnya. Dan melalui susunan acara maulid nabi ini pula jamaah masjid al huda dapat mengambil nilai dakwah yang kemudian dapat di aplikasikan dalam kehidupan nyata. Nilai dakwah tersebut antara lain nilai keagamaan, nilai pengetahuan, nilai solidaritas, nilai ekonomi dan nilai kesenian. Nilai nilai tersebut terkandung dalam susunan acara maulid nabi jamaah masjid al huda desa karang joho kecamatan badegan
\end{abstract}

Kata Kunci : Nilai Dakwah, Maulid Nabi , Masjid Al - Huda

\section{Abstract}

The purpose of researching the value of da'wah in the tradition of the Prophet Jama'ah Jama'ah Masjid Al Huda is to find out how the Maulid Nabi tradition is carried out and what da'wah values are contained in the tradition. behind the Al Huda mosque congregation, so that the implementation of the Prophet's birthday is not just an annual agenda for them. Through this, the implementation of the Prophet's birthday is more impressive and has a good impression on the congregation of the Al Huda mosque, this is of course the value contained therein. In this study the author uses a sociological approach by conducting participatory observations and interviews as the main method of data collection. While the method used is descriptive qualitative which has the characteristics of direct data sources, descriptive. Triangulation is a technique of examining data by utilizing something else as a comparison outside of the data found, taking the subject in the environment of the Al Huda mosque congregation. The conclusion of this study is Background The background of education and the lack of information containers at that time made the congregation not understand or properly interpret the real prophet's birthday. through small things in the implementation of the Prophet's birthday in the Al 
Huda mosque environment, the congregation takes more value in it, the simplicity of ambengan (food) for example. And through this arrangement of the Prophet's birthday, the Al Huda mosque congregation can also take the value of da'wah which can then be applied in real life. The da'wah values include religious values, knowledge values, solidarity values, economic values and artistic values. These values are contained in the arrangement of the birthday of the Prophet Jama'at Al Huda Mosque, Karang Joho Village, Badegan District

Keywords: Value of Da'wah, Maulid Nabi, Masjid Al-Huda

\section{A. Pendahuluan}

Peringatan Maulid Nabi merupakan sebuah kegiatan keagamaan yang mendunia di kalangan masyarakat Islam. Tradisi Maulid Nabi Muhammad SAW merupakan tradisi yang unik, karena tradisi ini tidak muncul dan berkembang di kalangan masyarakat Timur Tengah khususnya Makkah dan Madinah yang notabenya adalah tempat kelahiran Nabi Muhammad. Tradisi ini dikembangkan di negeri yang amat jauh dari Makkah dan Madinah, tepatnya Mesir. Berkembangnya tradisi tersebut yang tidak pada tempat tinggal nabi membawa konsekwensi logis bagi perkembangan tradisi tersebut. Varian - varian tradisi muncul beraneka ragam di setiap belahan dunia Islam. Dan di beberapa masa sejak Maulid Nabi pertama kali di laksanakan di masa Dinasti Fatimi. Hal ini di tertulis dalam karya Hasan as-Sundubi, yang menyatakan bahwa penguasa Fatimi yang kala itu menetap di Mesir, al-Muiz li-Diin Allah (memerintah 341 H/953-365 H/975 H), merayakan Maulid Nabi Muhammad SAW untuk pertama kali dalam sejarah Islam. Tidak jauh berbeda dengan belahan dunia lain, di Indonesia tradisi Maulid Nabi mengalami perkembangan yang sangat pesat. Awalnya hanya membaca cerita sejarah lahir nabi yang lebih terkenal dengan nama Barzanji, diba'i atau al-burdah kini berkembang menjadi perayaan yang penuh warna. Perayaan yang penuh warna tersebutlah yang kemudian menjadi sebuah tradisi yang sangat kuat berkembang di masyarakat Indonesia. Bahkan tidak jarang jarang muncul cerita-cerita mistis dalam perayaan tersebut.

Cerita mistis tersebut demikian tampaknya masih dialami oleh jama'ah Masjid AlHuda Desa Karang Joho Kecamatan Badegan sekarang ini. Dengan latar belakang masyarakat menengah ke bawah juga sebagian warga dengan bekal pendidikan yang minim semakin menjadi penyebab minimnya pengetahuan mereka terkait filosofi dan histori dari sebuah tradisi, khususnya peringatan Maulid Nabi. Padahal, Maulid Nabi tidak hanya berhenti pada peleksanaan ritual. Umat Islam mestinya melaksanakan ajaran Nabi Muhammmad SAW dan meneladani semua perilaku beliau. Dalam hal merayakan Maulid Nabi, di jama'ah Masjid Al-Huda Desa Karang Joho Kecamatan Badegan ini ialah dengan membawa nasi ambeng,

Kemudian dibawa ke Masjid beserta menunaikan sholat Isya' berjama'ah yang setelah itu para jamaah laki-laki dan beberapa jamaah perempuan, berkumpul dan membaca shalawat Nabi dan dilanjutkan dengan do'a bersama atau kenduri, sebelum di akhiri dengan menikmati dan membagi nasi ambeng kegiatan tersebut juga diisi dengan ceramah oleh tokoh agama. Memang pada umumnya dalam pelaksanaan tradisi terdapat dominasi peran antara laki-laki dan perempuan, tidak berbeda pula dengan tradisi di atas, akan tetapi perbedaan antara laki-laki dan perempuan hanya masalah kultur yang disosialisasikan dan dibentuk sesuai dengan kebudayaan setempat. Hal itu dirasa harus diubah seiring berkembangnya waktu, karena tradisi tidak sematamata menunjuk pada suatu norma, adat kebiasaan lama yang berlangsung hingga kini dan 
dilestarikan. Akan tetapi tentang pengetahuan tradisi juga harus dikenalkan dan dinikmati oleh semua kalangan tanpa pandang status sosial, jenis kelamin dan usia, terlebih tradisi berakar keagamaan seperti Maulid Nabi.

Dalam peringatan Maulid Nabi ini banyak sekali prosesi yang dilakukan oleh masyarakat yang melaksanakanya hal ini tak lepas dari adat kebiasaan yang sudah menjamur di jama'ah masing masing, meskipun pada dasarnya perayaan ini mempunyai tujuan yang sama yaitu mengenang perjuangan Nabi Muhammad SAW. Ada beberapa tradisi Maulid di Indonesia, contohnya di Banten, masyarakat Banten biasanya merayakan Maulid Nabi di kompleks Masjid Agung Banten sambil berziarah ke makam sultan-sultan yang ada di kompleks di Masjid tersebut. Beberapa orang percaya bahwa jika mereka berendam didalam kolam kompleks Masjid tersebut, mereka bisa mendapat berkah. Tak jarang pula mereka membawa pulang airnya yang dipercayai sebagai obat. Lain daerah lain prosesi, begitulah gambaran masyarakat kita dalam menyambut dan merayakan Maulid Nabi, akan tetapi lepas dari berbagai macam perayaan dan sebab musababnya adalah tentang pemahaman penuh dari masyarakat tentang hakikat Maulid Nabi yang sebenarnya. Terlebih untuk masyarakat awam, perayaan ini bagi mereka ialah perayaan tahunan yang mana mereka harus ikut andil didalamnya dengan membuat makanan, menyerahkan hasil bumi dari ladang mereka, membersihkan dan mengunjungi makam leluhur mereka dan yang lain.

Maulid Nabi Muhammad SAW atau yang kadang kadang di sebut maulud nabi, muludan atau maulid saja, adalah peringatan hari lahir Nabi Muhammad SAW, yang di Indonesia perayaannya jatuh pada setiap tanggal 12 Rabiul Awal dalam penanggalan hijriyah. Perayaan Maulid Nabi merupakan tradisi yang berkembang di masyarakat Islam jauh setelah Nabi Muhammad SAW wafat. Secara subtansi, peringatan ini adalah ekspresi kegembiraan dan penghormatan kepada Nabi Muhammad SAW.

Sangat diperlukan pemahaman masyarakat tentang adanya perayaan ini, karena Maulid Nabi merupakan suatu kegiatan atau momentum untuk mengenang perjuangan dan bentuk mahabbah terhadap Nabi Muhammad SAW. Dalam pemahaman tersebut bisa dikatakan tradisi Maulud Nabi sebagai media dakwah, yang memberikan teladan tentang kehidupan Nabi Muhammad SAW, jiwa kepemimpinanya, dan seruan kebaikan untuk umatnya. Pengertian yang luas, dakwah bukan menjadi tuntutan agama semata, tetapi juga tuntutan kemanusiaan dan kebenaran universal.

Dalam pengertian yang luas itu, dakwah bukan hanya berkaitan dengan persoalan menambah jumlah pemeluk Islam, akan tetapi yang paling utama adalah bagaimana dakwah dapat berpihak pada nilai nilai kebenaran dan kemanusiaan. Akan tetapi sampai hari ini masih banyak yang belum memahami dan memaknai Maulid Nabi. Kebanyakan dari mereka baru sekedar membaca riwayat dan kisah Nabi saja, namun tidak bisa memahami isinya, terlabih mengurai nilai nilai dakwah didalamnya.

\section{B. Metode Penelitian}

Pada penelitian ini penulis menggunakan pendekatan sosiologis, dengan menggunakan observasi partisipan dan wawancara sebagai metode utama pengumpulan datanya karena data 
yang dihasilkan berupa data deskriptif dalam bentuk pernyataan-pernyataan atau kata-kata tertulis yang berasal dari sumber data yang diamati dan diteliti agar lebih mudah memahami.

Sedangkan metode yang digunakan kualitatif yaitu penelitian yang hasilnya berupa data deskriptif melalui pengumpulan fakta-fakta dari kondisi alami sebagai sumberlangsung dengan instrumen dari peneliti sendiri. Metode Kualitatif sebagai prosedur penelitian yang menghasilkan data deskriptif berupa kata-kata tertulis atau lisan dari orang-orangdan perilaku yang dapat diamati.

Jenis penelitian yang digunakan peneliti adalah penelitian kualitatif (qualitative research) sebagai suatu penelitian yang ditujukan untuk mendeskripsikan dan menganalisis fenomena, peristiwa, aktifitas social, sikap,kepercayaan, persepsi, pemikiran orang secara individual maupun kelompok. Beberapa deskripsi tersebut digunakan untuk menemukan prinsip-prinsip dan penjelasan yang menuju pada kesimpulan.

\section{Pembahasan}

Salah satu dari beberapa macam-macam nilai yang mendasari perbuatan seseorang atas dasar pertimbangan kepercayaan bahwa sesuatu itu di pandang benar menurut ajaran agama. Dari hasil penelitian yang dilakukan peneliti, nilai tersebut sangat mendominasi tradisi Maulid Nabi tersebut. Sebab, di laksanakanya tradisi Maulid Nabi tidak lepas dari peringatan lahirnya nabi Muhammmad SAW. Yang mana seperti di kisahkan dalam al-qur'an bahwa nantinya akan ada rasul penutup para nabi. Dan Nabi Muhammad mempunyai andil yang sangat besar dalam kehidupan kaum muslimin. Sebab beliau lah yang mampu membawa peradaban manusia kearah kehidupan yang lebih baik lagi bermanfaat.

Dengan melaksanakan Maulid Nabi, umat muslim pada umunya dan jamaah Masjid AlHuda Karang Joho pada khusunya dapat merayakan lahirnya akhirul anbiyaa'. Serta sebagai penghormatan dan kecintaan pada Nabi MuhammadSAW, yang juga di sebut dengan kekasih Allah SWT. selain itu, jamaah Masjid Al- Huda juga dapat meneladani misi kerasulan Nabi MuhammadSAW, yang membawa ajaran islam rahmatan lil 'alamin sehingga ajaran islam dapat tersebar dan dapat tersebar secara merata.

Hal tersebut sama dengan ungkapan Ali Sukasno salah satu tokoh agama sekaligus kyai di jama'ahMasjid Al- Huda bahwa Dilaksanakanya Maulid Nabi ini dimaksudkan sejak awal oleh Kyai Mustofa bahwa untuk semakin cintannya masyarakat khususnya di jama'ah Masjid AlHuda desa Karang Joho ini kepada nabi Muhmmad. Bukan semata mata untuk berkumpul dan melaksanakan tradisi saja. Kyai kan pada waktu itu seperti bisa melihat bagaimana masa mendatang. Jadi ya manfaatnya berlipat lipat.

Sekalipun sekarang ini islam sudah mendominasi negeri, akan tetapi misi berdakwah seperti nabi tetap harus dilaksanakan. Sebab dakwah juga berarti mengajak dalam kebaikan yang lebih baik menurut agama, mengingatkan dalam kebaikan. Dan senada dalam salah satu nilai dakwah yang di tulis oleh Abd Rahim Arsyad bahwa nilai dakwah yang beliau sebut bil hikmah adalah suatu kegiatan yang dijalankan dengan konsep dan penuh flexibel(tidak ada paksaan). dan di tengah tengah acara atau kegiatan da'I (tokoh agama) dapat memberikan diagnosa juga 
penjelasan yang tepat kepada jamaah danmampu meletakkan dakwahnya sesuai yang dibutuhkan masyarakat.

Salah satu dari macam macam nilai yang mendasari perbuatan seseorang terhadap orang lain atau satu orang ke orang yang jauh lebih banyak tanpa menghiraukan akibat yang mungkin timbul terhadap dirinya sendiri, baik itu suatu keberuntungan ataupun kerugian. Apalagi di dalam islam sendiri telah dijelaskan bahwa kita semua bersaudara. Baik antara muslim atau non muslim, si kaya si miskin, pada hakikatnya kita sama. Sama sama keturunan nabi adam dan hawa sebagai ciptaan Allah SWT. Nilai kerukunan yang baik, akan tercipta suatu hubungan persaudaraan (ukhuwah islamiyah) yang erat. Sehinggan akan tercipta rasa kekeluargaan yang sangat tinggi serta munculnya sikap tolong menolong, sekalipun berbeda kampung, kota, suku, ras dan negara. Sebagaimana dalam firman Allah SWT dalam surat Al Hasyr :9 (adapun orang yang telah lebih dari mereka dan bertempat tinggal di kampung dan beriman, mereka tunjukkan kasih sayang kepada orang yang berpindah dari kampung mereka dan tiada merekamenaruh keinginan dalam hati mereka terhadap apa yang di berikan pada mereka (yang berpindah) bahkan mereka mengutamkan kawanya lebih dari diri mereka sendiri ,meskipun dirinya sedang kesusahan. Siapa yang terpelihara dari kekikiran jiwanya merekalah yang beruntung)

Merupakan salah satu dari macam - macam nilai yang mendasari perbuatan seseorang atau sekelompok orang yang bekerja terutama atas dasar pertimbangan rasional, nilai keilmuan ini biasa di sandingkan dengan nilai agama. Selain dari memberikan pengajaran pada anak di tanamkanya rasa kepedulian sosial dan agama, tradisi Maulid Nabi ini juga mengandung pola kesederhanaan. Tradisi Maulid Nabi yang di Masjid Al- Huda ini tidak memerlukan ornamen ornamen yang sulit di dapat bahkan di sesuaikan dengan kemampuan masing masing. Menurut peneliti nilai pengetahuan dan pendidikan ini juga terkandung dalam tradisi Maulid Nabi di Masjid Al- Huda, diantaranya:

\section{Kesederhanaan}

Pola kesederhanaan dalam tradisi ini adalah tidak adanya unsur memberatkan bagi masyarakat dan tidak adanya unsur menghambur hamburkan uang /segala yang mubadzir, yang membawa kemudharatan. Seperti rebut gunungan makanan, mercon (petasan), dan yang lainya. Adanya tradisi Maulid Nabi ini mengandung unsur bahwa harta itu mempunyai fungsi sosial dan pembagian yang rata.Melalui pengeluaran sedekah dapat membersihkan jiwa seseorang dari sifat kikir dan tamak.

Sehingga harta tidak hanya beredar di kalangan orang orang yang mampu, akan tetapi juga beredar di kalangan orang yang tidak mampu. Dalam istilah lain di sebutkan "yang kaya makin kaya", "yang miskin makin miskin" Pengajaran atau pengetahuan semacam itu akan berdampak baik bagi anak di kemudian hari, sebab sifat dan sikap seperti itu memang harus dimiliki setiap orang. Nilai ini juga bukan untuk pengetahuan anak saja, namun juga untuk lebih ringanya seseorang yang dianggap mampu dalam masyrakat untuk bersedekah.

Unsur dakwah tentunya terkandung dalam penjelasan diatas, mengingat bersedakah bukan hanya karena pahala di akhirat kelak. Akan tetapi dalam bersedakah tentunya dapat menularkan keinginan orang lain untuk melakukan kebaikan serupa. Jadi secara tidak langsung 
kita juga bisa berdakwah ( menyebarkan kebaikan pada orang lain) yang tentunya kesemuanya tersebut harus di landasi dengan keikhlasan.

2. Tausiyah

Dalam tausiyah atau ceramah, tidak saja terkandung nilai agama, akan tetpi pengetahuan juga terkandung didalamnya. Sebab dalm tausiyah ustadz juga memaparkan sejarah Nabi MuhammadSAW, kisah yang harus diteladani dan juga tentang kehidupan beliau pada saat itu. Selain diajarkan dengan kisah sang teladan, para jamaah juga diajarkan untuk selalu bersyukur dengan segala nikmat yang terlimpah. Jamaah yang hadir acara Maulid Nabi juga tidak saja orang dewasa, akan tetapi juga anak anak dan para pemuda yang tentunya hal tersebut akan menambah wawasan keagamaan mereka.

Nilai keilmuan sangat kental juga dalam disampaikanya tausiyah di acara Maulid Nabi ini. Sebab, didalamnya dapat diambil point point ilmu agama, yang dapat menambah wawasan para jamaah. Sehingga jamaah tidak hanya sebuah rutinitas saja akan tetapi juga pengetahuan, keyakinan, yang di praktekkan.

Merupakan salah satu dari macam macam nilai yang mendasari perbuatan seseorang atau sekelompok orang atas dasar pertimbangan rasa keindahan atau rasa seni yang terlepas dari pertimbangan material. Nilai kesenian ini juga terdapat dalam tradisi Maulid Nabi yang mana dalam sesi istirahat di acara ini, jamaah akan mendapat suguhan hiburan dari remaja masjid dan anak anak maddin jama'ah masjid. Hiburan biasanya berupa seni hadrah (yaitu irama yang ditimbulkan oleh tabuhan rebana . hadrah ini berisi dengan syair syair islami yang mengandung pujian dan keteladanan sifat Allah SWT dan rasulullah SAW. Dengan demikian seni hadrah ini akan membawa dampak kecintaan pada Allah SWT dan Rasulnya. Hadrah bukan saja menyemarakkan acara islami seperti Maulid Nabi, namun juga di acara tabligh akbar, perayaan tahun barudan peringan hari hari besar lainya.

Dari penjelasan diatas dapat disimpulkan pula bahwa nilai seni di dalam tradisi Maulid Nabi ini, dapat menjadi media dakwah atau perantara antara pelaku dakwah (dalam hal ini pemain hadrah) dan pendengar.Untuk dapat menerima dengan baik pesan dan maksud yang disampaikan lewat hiburan tersebut.

Islam telah mengajarkan untuk seimbang dalam memikirkan kehidupan di dunia dan akhirat. Memikirkan kehidupan di dunia untuk mencukupi kebutuhan sifat lahiriyah manusia, sedangkan memikirkan kehidupan akhirat untuk mencari bekal kehidupan di akhirat yaitu yang berupa amal perbuatan dan beribadah kepada Allah SWT.Tradisi Maulid Nabi satu sisi mendekatkan diri pada Allah SWT dan satu sisi membawa rezeki tersendiri bagi pedagang pasar di sekitaran desa ketika hendak menjelang pelaksanaan Maulid Nabi. Mereka mengaku bahwa penghasilan mereka menjelang pelaksanaan Maulid Nabi ini sangat meningkat di bandingkan hari hari biasa. Hal ini dikarenakan pelaksanaan Maulid Nabi juga di laksanakan di tempat lain, seperti yang dilaksanakan oleh jemaah Masjid Al- Huda. Dan banyak warga yang membeli berbagai macam kebutuhan dan makanan untuk di sajikan di acara Maulid Nabi. Seperti penjual ayam, daging, snack box dan bahan makanan lainya.

Terdapat kesinambungan dalam nilai ekonomi dan solidaritas bukan saja kesinambaungan namun juga saling menguntungkan. Serta dua hal tersebut juga termasuk dalam moment dakwah, artinya ketika ada sesuatu perbuatan baik seperti di dalam menyuguhkan hidangan dan menimbulkan eratnya silaturrahmi yang kian erat. Dari data diatas diketahui bahwa hubugan antara media dakwah yang tepat, obyek dakwah yang tepat, subyek dakwah yang kreatif dan pemilihan materi dakwah yang benar membuat hasil yang nyata dan memuaskan. 


\section{Kesimpulan}

Dari penelitian yang dilakukan peneliti maka dapat disimpulkan sebagai beikut Pelaksanaan maulid nabi yang dilakukan oleh jamaah masjid Al Huda desa Karang Joho adalah dengan membawa nasi ambeng ke masjid, yang kemudian di santap bersama sama dan berkelompok usai tahli dan tausiyah dari da'i yang sudah di tunjuk panitia. Usai santap bersama nasi ambeng kemudian acara diakhiri dengan do'a dan pennutup. Dan dilanjutkan kembali dengan pembacaan syair barjanzi, namun acara ini non formal tidak ada panduan secara langsung dari MC.

Nilai dakwah yang terkandung pada tradisi maulid nabi jama'ah masjid al-huda adalah nilai keagamaan, nilai pengetahuan, nilai solidaritas, nilai ekonomi dan nilai kesenian. Nilai nilai tersebut terkandung dalam susunan acara maulid nabi jamaah masjid Al Huda desa Karang Joho kecamatan Badegan.

\section{Daftar pustaka}

A. Rosyad Shaleh. 1977. Management Dakwah Islam. Jakarta: Bulan Bintang Amin Akhsan Ishlahi. 1985. Metode Dakwah Menuju Jalan Allah. Jakarta: Litera Antara Nusa Asmuni Syyukur, 1983,Dasar-Dasar Strategi DakwahSurabaya: Al-Ikhlas Hizair MA, "KamusLengkapBahasa Indonesia", Kaptein Nico, 1994Perayaan Hari Lahir Nabi Muhammad SAW Jakarta:INIS Khusniati Rofiah. 2010.Dakwah Jamaah Tabligh dan Eksistensinya di Mata masyarakat. Ponorogo: STAIN Press

Lexy Moleong,2005Metodologi Penelitian KualitatifBandung Remaja Rosdakarya Samsul Munir Amin,1985 "Ilmu Dakwah" (Jakarta: AM Toha Jahja Omar

Sholikin Muhammad, 2005 Di Balik 7 Hari Besar Islam (Sejarah, Makna Dan Amaliah), Garudhawaca

Surachmad Winarno 1978 , Dasar dan Teknik Research Pengantar Metodologi Ilmiah (Bandung: Tarsito, 978)

Sulthon muhammad,2003Desain Ilmu DakwahSemarang :Pustaka Pelajar, Samsul Munir Amin,1985 “Ilmu Dakwah" (Jakarta: AM Toha Jahja Omar

Wahidin Saputra,20011 "Pengantar Ilmu Dakwah" (Jakarta: Rajawali https://id.wikipedia.org 